\title{
Application of Biosensors in Cancers, An Overview
}

\author{
Sameer Quazi ${ }^{1,2, *}$ \\ 1. GenLab Biosolutions Private Limited, Bangalore, Karnataka, India. (560043) \\ 2. Department of Biomedical Sciences, School of Life Sciences, Anglia Ruskin University, \\ United Kingdom. \\ *Corresponding Author. (colonel.quazi@gmail.com)
}

\begin{abstract}
:
The deadliest disease in the world, cancer, kills many people every year. The early detection is the only hope for the survival of malignant cancer patients. As a result, in the preliminary stages of , the diagnosis of cancer biomarkers at the cellular level is critical for improving cancer patient survival rates. For decades, scientists have focused their efforts on the invention of biosensors. Biosensors, in addition to being employed in other practical scenarios, can essentially function as cost effective and highly efficient devices for this purpose. Traditional cancer screening procedures are expensive, time-consuming, and inconvenient for repeat screenings. Biomarker-based cancer diagnosis, on the other hand, is rising as one of the most potential tools for early detection, disease progression monitoring, and eventual cancer treatment. As Biosensor is an analytical device, it allows the selected analyte to bind to the biomolecules being studied ( - for example RNA, DNA, tissue, proteins, cells). They can be divided based on the kind of biorecognition or transducer elements on the sensor. Most biosensor analyses necessitate the analyte being labeled with a specific marker. In this review article, the application of distinct variants of biosensors against cancer has been described.
\end{abstract}

Keywords: Biosensors, DNA,RNA, Biomarkers, Proteins, Tissue

\section{Highlights:}

1. Cancer is the second deadliest disease in the world.

2. Early diagnosis of cancer can prevent mortality rates.

3. Nanomaterials based biosensors are being used in the medical field.

4. Biosensors are cost effective than traditional cancer detection method.

5. Biosensors are able to detect distinct variety of cancer biomarkers. 


\section{Introduction:}

Cancer is famed to be the second lethal disease as it causes a large mortality in the worldwide after cardiovascular disease. The number of deaths regarding cancer has been ex-peed 1500 per day. It is a hypothesis by scientists that in every next year, 1 in 3 men will be diagnosed with distinct type of cancer. Cancer can come in more than 200 different forms, including breast, lung, hematologic, ovarian, skin, prostate, and colon cancer, as well as leukemia. Environmental factors like alcohol, radiation, tobacco smoke and chemicals, as well as genetic factors like autoimmune dysfunction and inherited mutations and, all raise the chances of cancer formation. Bacterial and viral infections are also linked to some types of cancer such as cervical cancer and stomach cancers respectively). Each year, there are about two hundred thousand new cases of prostate and breast cancer in both men and women, which is the most common type of cancer in both groups. The early detection of cancer is very important for the survival of patients and the success of their treatment. This is why sensitive and specific methods are needed for early cancer detection. A lot of people are afraid of cancer, and it still kills a lot of people around the world. Prostate, lung, breast, and colon cancer killed the most people in the United States and Canada in 2006 [1,2]. There were 154,162 people who died of cancer in UK in the year of 2006 (Cancer Research UK [3]). There has been a lot of advancement in the technology, but the late diagnosis and poor prognosis is the main reason of the low survival of cancer patients. Due to their reliance on the phenotypic features of the tumor, traditional procedures such as magnetic resonance imaging, biopsies, and ultrasound are ineffective for early-stage cancer identification [4]. As, Cancer is a complex and multistage disease, and its genesis and progression relate to a complex array of genetic and epigenetic changes that disrupt cellular signaling and result in tumorigenic malignancy and transformation [5].

Although early intervention raises the possibility of effective therapy, a new method of cancer diagnosis is urgently needed. Numerous researchers believe that cancer biomarkers, or minor changes in the chemical or genetic composition of the body, can be detected in the very early stages of cancer, so assisting in early diagnosis. According to Jayanthi (2017) and a group of Indian academics, these mutations or abnormalities "may operate as nucleic acid-based biomarkers in diagnosis" [6]. Cancer can be discovered early on by checking for tiny abnormalities. According to a group of Russian researchers, abnormal levels of these biomarkers can be discovered by monitoring, assisting in early diagnosis and successful therapy [7]. These researchers believe, biomarkers have enormous potential to change cancer detection. Nanotechnology, according to a group of researchers at ETH Zurich, is a viable answer for recognizing diseases [such as cancer] and managing health problems [8].

Biomarkers are molecules that experience significant changes during cancer and have a high therapeutic relevance. Proteins, isoenzymes, nucleic acids, metabolites, or hormones are all examples of biomarkers. They are categorized as prognostic, predictive, or diagnostic [9]. Diagnostic biomarkers are used to diagnose disease, whereas prognostic biomarkers provide information regarding the disease's course of recurrence. On the other side, predictive biomarkers are used to measure treatment response [10,11] Often, a change in the degree or presence or absence of biomarkers in a cell indicates the development of cancer. Cancer-specific detection and identification of these biomarkers may aid in early disease monitoring and diagnosis [12]. The 
classic enzyme-linked immunosorbent assay (ELISA) or polymerase chain reaction (PCR)-based methods for biomarker identification have technological constraints, including the high cost of chemicals used in each assay and the sluggish detection rate [13]. Additionally, because they are hand-operated techniques, they are not capable of providing continuous observation of the patient during therapy.

Cancer is being studied using novel and emerging molecular approaches, which is leading in a better understanding of the illness and the finding of potential new genomic and proteomic biomarkers. To solve the difficulties associated with cancer diagnosis, multi-analyte analysis based on lab-on-a-chip point-of-care devices (POC) is required [14]. Currently, research in this area is accelerating, and a plethora of new diagnostic tools are being produced. Numerous biosensor platforms for cancer disease diagnosis have been described in the literature. Biosensors are used to detect and quantify certain biological markers or analytes (e.g., proteins, DNA, RNA, and cells) by converting biological molecule interaction signals to an electrical signal that can be quantified as a digital output. Additionally, biosensor technology can provide accurate and timely information, as well as to quantify cancer cells and metastases. Furthermore, it can be utilized to examine the therapeutic efficacy of anticancer medications, cancer biomarkers, and the efficacy of therapies at multiple target areas. Biosensors are an emerging tool for the management of a variety of diseases, with promise for cancer detection and monitoring. In general, these biosensors are designed to shorten the time required to diagnose a patient's ailment and to track therapeutic success. In this review article, a brief explanation of the application of biosensors in various cancer has been elucidated. The potential usages of biosensors for example: electrochemical biosensors, fluorescence biosensors, optical biosensors, mass sensitive etc. in cancer research has been briefly explained in this article.

\section{What is Biosensors and How does they function? :}

A biosensor is composed of two primary components: a bioreceptor and a transducer. Bioreceptor is a term that refers to a biological component (tissue, germs, organelles, cell receptors, enzymes, antibodies, nucleic acids, etc.) that identifies the target analyte. The other component is the transducer, a physicochemical detector that converts the recognition event to a quantifiable signal $[15,16]$. A biosensor's function is determined by the biochemical specificity of the biologically active substance. The biological material to be used will be determined by a variety of parameters, including its specificity, storage capacity, operational stability, and environmental stability [15,17]. Biosensors have a wide range of potential uses in biomedicine, industry, and defense. Thus far, the primary use has been in blood glucose sensing, owing to the large market opportunity $[18,19]$.

Biological sensing elements have included biomolecules such as enzymes, antibodies, receptors, organelles, and microbes, as well as animal and plant cells or tissues [15]. Microorganisms have been combined with a few transducers to create biosensor devices [16, 20, 21]. These transducers include amperometric, potentiometric, calorimetric, conductimetric, colorimetric, luminescence, and fluorescence. There are distinct types of biosensors which has been utilized in the medical field for years. In the following table 1 and figure 1 , the distinct types of biosensors are described and illustrated below: 
Table 1: Different types of Biosensors

\begin{tabular}{|c|c|}
\hline Types of Biosensors & Functions \\
\hline 1. Optical Biosensor & $\begin{array}{l}\text { For this type of biosensor, the light that comes out of it is the signal that is } \\
\text { being measured. When making the biosensor, one might use optical diffraction } \\
\text { or electrochemical luminescence to make it function. } \\
\text { Optical transducers are great for applications that does not need to use labels to } \\
\text { find bacteria. There are sensors on the surface of the transducer that can pick } \\
\text { up on very small changes in refractive index or thickness that happen when } \\
\text { cells attach to receptors that have been put there. In this way, they link changes } \\
\text { in the concentration, mass, or number of molecules to changes in how light } \\
\text { looks. A lot of different optical methods have been used to look for bacterial } \\
\text { pathogens. These include monomode dielectric waveguides (SPR), } \\
\text { ellipsometry, the resonant mirror, and the interferometer [22-24]. }\end{array}$ \\
\hline $\begin{array}{l}\text { 1.1Piezoelectric } \\
\text { biosensors }\end{array}$ & $\begin{array}{l}\text { Using a Piezoelectric (PZ) biosensor, one can get real-time results, make it easy } \\
\text { to use, and save money. For example, you could put antibodies to bacteria on } \\
\text { the surface of the PZ sensor and then put it in a solution with bacteria in it. This } \\
\text { is the general idea. In this case, the bacteria will attach to antibodies, which } \\
\text { will make the crystal's mass grow, and the resonance frequency of oscillation } \\
\text { will go down as a result }[22,24] \text {. }\end{array}$ \\
\hline $\begin{array}{l}\text { 1.2 Surface plasmon } \\
\text { resonance (SPR) } \\
\text { biosensor }\end{array}$ & $\begin{array}{l}\text { A thin layer of gold is used to make evanescent field-based optical sensors that } \\
\text { can be used for things like sensing. Photo-detector array sensors are used to } \\
\text { look for reflection minima in the flow of analyte over an immobilized } \\
\text { interactant on a gold surface. SPR has been used to find pathogen bacteria by } \\
\text { detecting them through immunoreactions }[24,25] \text {. }\end{array}$ \\
\hline 2. Thermal Biosensors & $\begin{array}{l}\text { One of the most important things about biological reactions is that they either } \\
\text { take in or produce heat, which changes the temperature of the environment } \\
\text { where the reaction happens. This type of biosensor makes use of this fact. They } \\
\text { are made by attaching enzyme molecules to temperature sensors. Heat from the } \\
\text { enzyme is measured when it encounters the analyte, and the analyte } \\
\text { concentration is used to figure out how much of the enzyme is used. This type } \\
\text { of biosensor can be used to detect pesticides and harmful bacteria [24]. }\end{array}$ \\
\hline 3.Resonant Biosensors & $\begin{array}{l}\text { An acoustic wave transducer is connected to an antibody (bio element) in this } \\
\text { form of biosensor. When an analyte molecule (or antigen) binds to the } \\
\text { membrane, the membrane's mass changes. The ensuing shift in mass alters the } \\
\text { transducer's resonance frequency. This difference in frequency is then } \\
\text { quantified [26]. }\end{array}$ \\
\hline $\begin{array}{l}\text { 4.Electrochemical } \\
\text { biosensors }\end{array}$ & $\begin{array}{l}\text { Electrochemical biosensors are mostly used to look for hybridized DNA, DNA- } \\
\text { binding drugs, glucose concentration, and other things. }\end{array}$ \\
\hline
\end{tabular}




\begin{tabular}{|c|c|}
\hline & $\begin{array}{l}\text { These electrochemical biosensors can be broken down into three types based } \\
\text { on the way they measure electricity: i. conductimetric, (ii) amperometric, and } \\
\text { (III) potentiometric. Electrochemistry is better than optical methods because it } \\
\text { allows the analyst to work with turbid samples, and the cost of the equipment is } \\
\text { much less than with optical methods. } \\
\text { Electrochemical methods, on the other hand, have a little less selectivity and } \\
\text { sensitivity than optical methods [22,27]. }\end{array}$ \\
\hline $\begin{array}{l}\text { 4.1 Conductimetric } \\
\text { Biosensors }\end{array}$ & $\begin{array}{l}\text { The electrical conductance or resistance of the solution is what is being } \\
\text { measured. This is because when electrochemical reactions produce ions or } \\
\text { electrons, the conductivity or resistivity of the whole solution changes. A } \\
\text { proper scale is used to measure this change. Conductance measurements have a } \\
\text { low level of sensitivity. }\end{array}$ \\
\hline $\begin{array}{l}\text { 4.2Amperometric } \\
\text { Biosensors }\end{array}$ & $\begin{array}{l}\text { In biosensors, this is one of the most common ways to detect changes in } \\
\text { electrochemistry. This high-sensitivity biosensor can tell if there are } \\
\text { electroactive substances in biological test samples. Amperometric biosensors } \\
\text { produce a current that changes with the concentration of the substance they are } \\
\text { trying to find. It is the Clark Oxygen electrode that is used in most } \\
\text { amperometric biosensors }[22,24] \text {. }\end{array}$ \\
\hline $\begin{array}{l}\text { 4.3. Potentiometric } \\
\text { Biosensors }\end{array}$ & $\begin{array}{l}\text { The oxidation or reduction potential of an electrochemical process is the } \\
\text { measured parameter in this sort of sensor, which is the least frequent of all } \\
\text { biosensors. However, several techniques may be discovered in this type of } \\
\text { sensor. The operating principle is since when a voltage is applied to an } \\
\text { electrode in solution, electrochemical processes produce current flow. The } \\
\text { voltage at which these reactions take place denotes a specific reaction and } \\
\text { species [24]. }\end{array}$ \\
\hline $\begin{array}{l}\text { 5.Nucleic Acid-based } \\
\text { Biosensors }\end{array}$ & $\begin{array}{l}\text { A nucleic acid biosensor is a device that combines an oligonucleotide with a } \\
\text { signal transducer for analysis. The nucleic acid probe is mounted on the } \\
\text { transducer and serves as a bio-recognition molecule for DNA/RNA fragment } \\
\text { detection [24]. }\end{array}$ \\
\hline $\begin{array}{l}\text { 6.Bioluminescence } \\
\text { sensors }\end{array}$ & $\begin{array}{l}\text { Bioanalytical sensors have made it possible to use the ability of some enzymes } \\
\text { to make photons as a byproduct of their work. This is known as } \\
\text { bioluminescence. The development of luciferase reporter phages sparked the } \\
\text { idea that bioluminescence could be used to find bacteria. The bacterial } \\
\text { luminescence lux gene has been used a lot as a way to see what is going on in a } \\
\text { lab. It can be turned on or off. In the inducible way, the lux gene is linked to a } \\
\text { promoter that changes when a compound of interest is present. As a result, the } \\
\text { amount of the compound can be measured by looking at how bright the } \\
\text { bioluminescence is. These systems have been used to find a wide range of }\end{array}$ \\
\hline
\end{tabular}




\begin{tabular}{|l|l|}
\hline 7.Nanobiosensors & microorganisms [24]. \\
& $\begin{array}{l}\text { Nano sensors are sensors that utilize nanotechnology. Nano biosensor } \\
\text { development is a relatively new accomplishment in the field of } \\
\text { Nanotechnology. Silver and certain other noble metal nanoparticles have a } \\
\text { wide variety of vital uses in the fields of biolabeling, drug delivery systems, } \\
\text { filters, and antibacterial medications as well as sensors [28]. }\end{array}$ \\
\hline
\end{tabular}

Figure 1 : A scheme of distinct variety of biosensors technology

\section{TYPES OF BIOSENSORS}

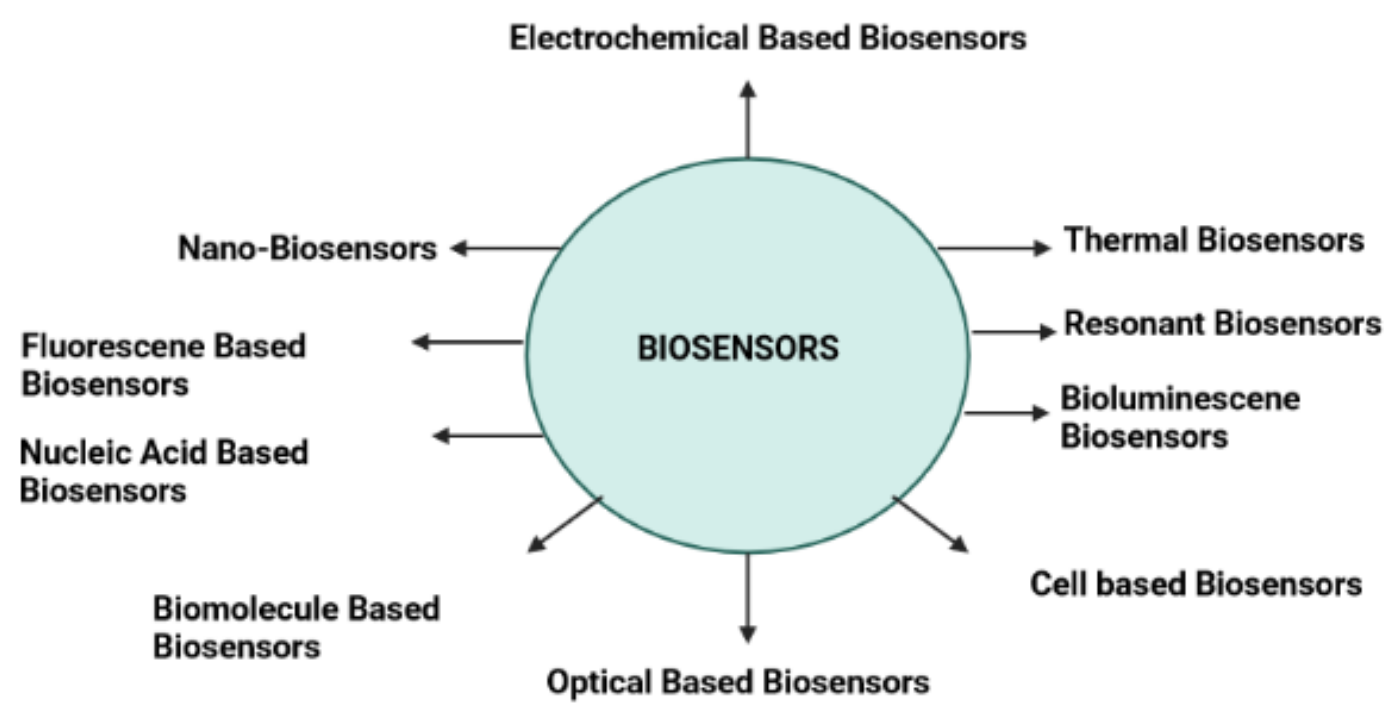

Biosensors and Cancer:

Biosensors have shown potential in the medical field, particularly in cancer research. Due to the increasing number of cancer occurrences worldwide each year, research into early cancer detection has become critical. Additionally, the idea of monitoring cancer treatment with biosensor techniques provides hope for personalized therapy. Which is why it is still desired to develop a more accurate and simplified approach at a cheaper cost that provides more information on the disease's etiology [30]. Special molecular- or cell-/tissuebased biosensors have already been created for these advanced studies and will be briefly described in the next sections. As a result of the non-invasive diagnosis and screening, researchers worldwide have begun designing and developing biosensors capable of efficiently detecting cancer. Biosensors are devices that are designed to detect a particular biological analyte by converting a biological entity (protein, DNA, or RNA) into a detectable and analyzed electrical signal [31]. The term "Bio" is used since the sensor detects 
biological elements. Enzymes, antibodies, microbes, and nucleic acids are all examples of biological substance. In the history of biosensor, the "father of biosensors," title goes to Professor Leland C Clark. His research on this technology has resulted in the development of the contemporary glucose sensor [32]. In the following context, the usage of distinct biosensors in various cancers are described below:

\section{Electrochemical Biosensors in Cancer Detection:}

The detection of biomarkers is primarily concerned with tracing proteins on the membrane surface of tumor cells and/or cancer-associated microRNA. While numerous different approaches for diagnosing such biomarkers have been reported, an electrochemical method is favored due to its low cost, rapid response, ease of operation, quantifiability, miniaturization potential, and high sensitivity and selectivity with a lower detection limit. Electrochemical biosensors are composed of three components: a biorecognition element, a signal transducer, and electrochemical systems composed of three electrodes [33,34]. Changes in the electrical signal trigger electrochemical reactions with target components on the electrode surface, which are subsequently monitored and recorded. To detect cancer biomarkers, a set of biorecognition elements has been developed. These elements include antibodies, enzymes, and synthetic molecules (such as aptamers, DNA fragments, and peptides) $[35,36]$. Biosensors are divided into immunosensors, aptasensors, enzymatic biosensors, and Geno biosensors, depending on the biorecognition elements utilized (nucleic acid biosensors).

\section{Nucleic acid based (NABs) biosensors:}

The normal cell signature is changed by a number of cancer-causing anomalies, such as the inactivation of the anti-tumor gene, the deterioration of the chromosomes, and the hypermethylation of a gene. Micro RNAs (miR) and p53 gene mutations are all examples of nucleic acid-based cancer biomarkers, which are things that cause cancer, like this. These biomarkers make it possible to diagnose cancer even if the patients don't show any physical signs. The most common way to immobilize something is to use thiolate-NABs to make a monolayer on a gold sensor surface.

The single-stranded DNA and RNA sequences could bind to the immobilized complementary sequences, and the type of interaction that happens depends on the molecules that are in the way.

This means that the Chargaff rules of base pairing (DNA: A=T, C=G; RNA) work for both DNA and RNA sequences when they are bound together. On these grounds, mutations in DNA or RNA that are linked to cancer may be found [37]. MicroRNAs (miRNAs) are very interesting molecules for cell research because they are small, non-coding ribonucleic acids that are found in all living things (RNA). They play a big part in cell development (proliferation, cell cycle progression, apoptosis) and are linked to a lot of different types of cancer. miRNA can be taken from cells or tissues. Even so, the amount of miRNA in cancer cells is different from that in normal cells $[38,39]$. There are synthetic DNA or RNA analogues with a different backbone than the sugar-phosphate backbone. It is called PNAs. PNAs are more specific and stronger when they connect with the right DNA or RNA strands because they have a pseudo-peptide backbone instead. It's possible to divide aptamers into two groups: DNA- or RNA-aptamers (short oligonucleotides) and peptide- 
aptamers (short peptide domains), but their detection is more like that of an antigen-antigen or receptorligand interaction. They can be easily changed or combined with a wide range of nanomaterials $[37,40]$. In the following table 2 and figure 2, the variety of nucleic acid-based detection are briefly illustrated:

Table 2: Nucleic Acid based Biosensors and their functionality against cancer

\begin{tabular}{|c|c|c|}
\hline $\begin{array}{l}\text { Nucleic Acid based Cancer } \\
\text { Biomarker Detection }\end{array}$ & Cancer Types & Functionality \\
\hline 1. DNA-DNA binding & Breast Cancer & $\begin{array}{l}\text { BRCA1 is one of the genes that causes breast } \\
\text { cancer when it is changed. It can be detected in } \\
\text { concentrations between } 10 \text { and } 100 \mathrm{M} \text { because of } \\
\text { the electrochemical biosensor. Short } \\
\text { oligonucleotides of DNA were stuck to zinc } \\
\text { oxide nanowires that were made with the } \\
\text { hydrothermal method and attached to a gold } \\
\text { electrode. Differential pulse voltammetry (DPV) } \\
\text { was used to look at how ssDNA combines with } \\
\text { other DNA [41]. }\end{array}$ \\
\hline 2.RNA -RNA binding & Breast Cancer & $\begin{array}{l}\text { In order to find mir21 in the total RNA of breast } \\
\text { cancer samples, an enzyme-based } \\
\text { electrochemical biosensor was used. mir21 was } \\
\text { attached to the pencil graphite electrode (PGE) } \\
\text { by coupling agents, and a biotinylated } \\
\text { complementary target was used to make the } \\
\text { hybridization happen with the help of the } \\
\text { coupling agents. After that, an avidin-labeled } \\
\text { alkaline phosphatase was added to the system so } \\
\text { that the biotin-avidin interaction could be seen. } \\
\text { Because of the enzymatic process that turned } \\
\text { alpha naphthol phosphate into alpha naphthol (- } \\
\text { NAP), DPV was used to look for the oxidation } \\
\text { signal in this study [38]. }\end{array}$ \\
\hline $\begin{array}{l}\text { 3.DNA aptamer-cells- } \\
\text { nanoparticles binding: }\end{array}$ & Blood Cancer & $\begin{array}{l}\text { Blood cancer is a type of cancer that can spread } \\
\text { very quickly. Leukemia cells may be attracted to } \\
\text { the QCM sensor by special DNA aptamers that } \\
\text { have been immobilized on it. Then, gold }\end{array}$ \\
\hline
\end{tabular}




\begin{tabular}{|l|l|l|}
\hline & & $\begin{array}{l}\text { nanoparticles (AuNPs) may be added to the cells } \\
\text { that have already been attached [42]. }\end{array}$ \\
\hline 4.PNA- RNA binding & Cervical Cancer & $\begin{array}{l}\text { It was used to find let-7b in the total RNA } \\
\text { extracts from HeLa cells (human epithelial } \\
\text { cervical cancer) by detecting base pairing. The } \\
\text { silicon nanowire field-effect transistors with } \\
\text { PNAs that were immobilized on them were used } \\
\text { to do this. With the best method, the detection } \\
\text { limit was 1 fM [39]. }\end{array}$ \\
\hline 5.DNA aptamer -antigen & Prostate Cancer & $\begin{array}{l}\text { The prostate-specific antigen (PSA) found in } \\
\text { blood samples is a well-known biomarker for } \\
\text { prostate cancer. The functionalization of a gold } \\
\text { sensor with a thiolated-DNA aptamer allowed for } \\
\text { the detection of PSA using a quartz crystal } \\
\text { microbalance in dissipation mode (QCM-D) with } \\
\text { an affinity constant of 37 nM. These studies } \\
\text { revealed not only the amount of PSA bound to } \\
\text { the sensor, but also the structure and hydration of } \\
\text { the aptamer layer [43]. }\end{array}$ \\
\hline
\end{tabular}

Figure 2: An overview of Nucleic Acid Based Biosensors and their detected cancer types

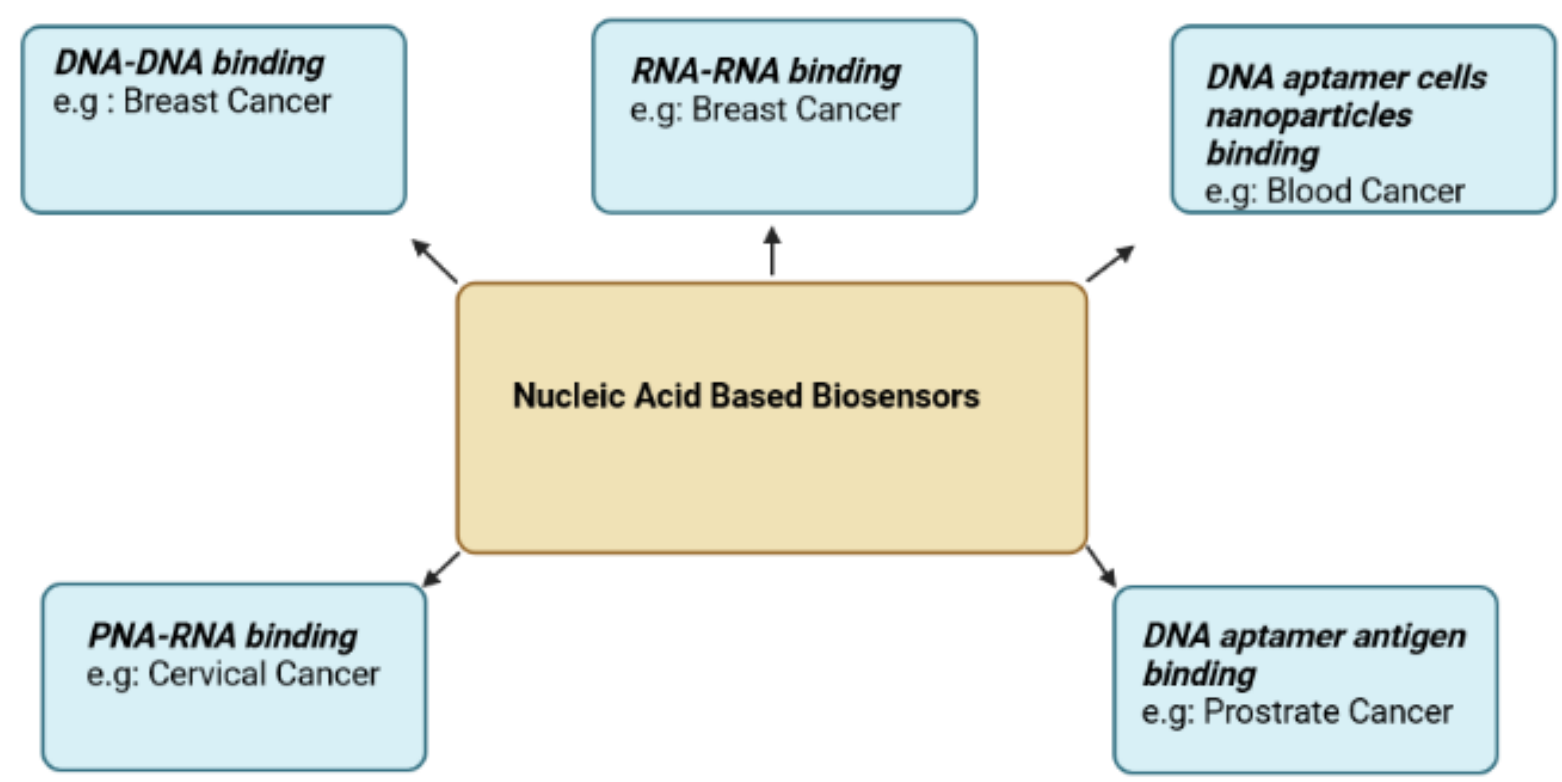




\section{Optical Biosensors against cancer:}

Optical platforms have established themselves as adaptable analytical approaches for a variety of biosensing applications by leveraging characteristics such as ease of operation, multiple analyte detection, and automated microfluidic systems [44]. An optical biosensor generates a quantifiable signal by monitoring the interaction of the recognition element with the target analyte [45] . Light-based sensors are also known as optical biosensors that can detect variations in certain light wavelengths. A luminescence, fluorescence, colorimetric, or interferometric transducer can be used. Variation in wavelengths or SPR in response to analyte recognition are converted into an electrical/digital readout using optical transducers [46]

Photonic crystal biosensors: Photonic crystal biosensors, which use an optical transducer, are a new type of biosensor. This type of biosensors can capture light from a tiny area which allows for higher measurement sensitivity, and then transmits it into a high electromagnetic field for display. This approach detects when and where cells or molecules connect to or are released from the crystal surface by measuring the light reflected by the crystal. Chan and colleagues used this sort of biosensor to track alternation in multiplication and death in breast cancer cells exposed to doxorubicin and establish the drug's IC50 [47]. This type of biosensor technology could be used to screen effective doses prior to therapy to balance therapeutic efficacy and toxicity.

The esophageal laser fluorescence-based optical biosensor: The esophageal laser fluorescence-based optical biosensor for the detection and observation of malignancies of the throat is another fascinating example of this sort of technology's application to cancer detection. The gadget sends a laser beam which emits a specific wavelength of light on an area of the esophagus after being eaten by the patient. Depending on whether the tissue includes malignant or normal cells, the esophagus wall reflects light at very precise wavelengths. Such sensor has been experimented on more than two hundred people and has been confirmed to correctly spot cancer $98 \%$ of the time [48-50]. Surgical biopsies, as well as the discomfort and recovery time associated with them, could be eliminated with the use of this sort of biosensor.

Piezoelectric and acoustic wave biosensors: Mass-based biosensors are comprised of piezoelectric and acoustic wave biosensors. Piezoelectric biosensors are more typically employed in cancer detection. The mass of quartz crystals varies when potential energy is given to them, which is what piezoelectric sensors are founded on. This mass change produces a frequency that can be translated into a signal. Microcantilever and piezoelectric immunosensors sensors have been found to be effective in detecting cancer biomarkers [47]. Dell'Atti and colleagues used a piezoelectric biosensor in combination with polymerase chain reaction multiplication to identify point mutations in the p53 gene of humans, which are implicated in practically all kinds of cancer [51].

Because p53 mutations are so important for cancer formation and therapy success, there has been a lot of work put into developing quick, affordable, and effective techniques to identify p53 alterations. 
Calorimetric biosensors: Calorimetric biosensors for cancer diagnostics are less prevalent than other biosensors, but the advent of nanotechnology to the field of biosensors has broadened the spectrum of applications for these biosensors. Exothermic processes are measured using calorimetric biosensors. Heat is produced by many enzyme activities, and alternation in the temperature can be utilized to determine analyte concentration. The result is monitored by enthalpy changes, which explains data about the substrate concentration indirectly [52]. Although calorimetric biosensors are not generally utilized for cancer diagnosis and prognosis, they have been shown to have some cancer-detecting capabilities. Medley and colleagues recently published a paper demonstrating the utilization of an aptamer-based gold nanoparticle calorimetric biosensor for cancer diagnosis. Using gold nanoparticles, the researchers were able to differentiate between two cell types: Burkitt's lymphoma cells and acute leukemia cells .This research shows aptamer-based identification elements can be used with a calorimetric transducer to identify mutated cells of cancers and possibly differentiate between normal and mutagenic cells [53]

\section{Whole cell or tissue-based biosensors for the diagnosis of Cancer:}

The major application of whole cell based or tissue-based biosensors are in cancer detection. In the following table 3 , some examples of whole cell-based biosensors against cancer are described below: 


\section{Table 3: Cell based Biosensors}

\begin{tabular}{|c|c|c|}
\hline Cell based Biosensors & Cancer types/Cell lines & Functionality \\
\hline Compound binding ability tests on cells & $\begin{array}{l}\text { Colorectal, Melanoma, } \\
\text { Tonsil, Prostrate, HeLa cell } \\
\text { lines etc. }\end{array}$ & $\begin{array}{l}\text { The initial and metastatic stages of human colorectal cancer cells were seeded onto a } \\
\text { gold QCM sensor covered with polystyrene, and the lectin-carbohydrate interaction } \\
\text { was evaluated using the lectin Helix pomatia agglutinin (HPA). Finally, HPA was } \\
\text { found to have a greater affinity for metastatic cells [54,55]. Lectin Con A was also } \\
\text { used to study the glycosylation level of melanocytes and melanoma cells (cultured on } \\
\text { QCM-D gold sensors coated with polystyrene). The study discovered that the } \\
\text { mannose and glucose types of oligosaccharides found on metastatic melanoma cells } \\
\text { have long and branching structures, but the oligosaccharides found on initial tumor } \\
\text { cells and normal cells are short and less ramified. Furthermore, Con A had a ten-fold } \\
\text { greater affinity for oligosaccharides on melanoma cells which are metastasis than on } \\
\text { premature tumor cells and melanocytes [56]. Cancer medication tests could also } \\
\text { benefit from cell-based biosensors. Herceptin is an antibody-conjugated medication } \\
\text { that identifies the overexpressed human epidermal growth factor receptor } 2 \text { (HER2) } \\
\text { protein in } 25-30 \% \text { of breast tumors. It causes cytostatic effects linked to cell cycle } \\
\text { arrest in the G1 phase, and antibody-dependent cell-mediated cytotoxity [57]. On the } \\
\text { contrary, histamines can activate G protein-coupled receptors (GPCRs) which are } \\
\text { very potential therapeutic target. A triphasic response of HeLa cells to histamine } \\
\text { contact was discovered in the SPR study:1- GPCRs prompted calcium release, 2-cell- } \\
\text { matrix adhesion changes after Protein Kinase C activation, 3-dynamic mass } \\
\text { redistribution in cells [58]. Interestingly, just a few tissue-based biosensors have been } \\
\text { characterized up to this point. Tonsil, prostate, and breast tumor samples were } \\
\text { collected and immobilized on the gold QCM sensor's surface. } \\
\text { The interaction of the rVAR2 protein with placental-like chondroitin sulfate, which is }\end{array}$ \\
\hline
\end{tabular}




\section{Biomolecule Based Biosensors:}

The biomolecule-based biosensors in cancer detection are jotted in the following table 4:

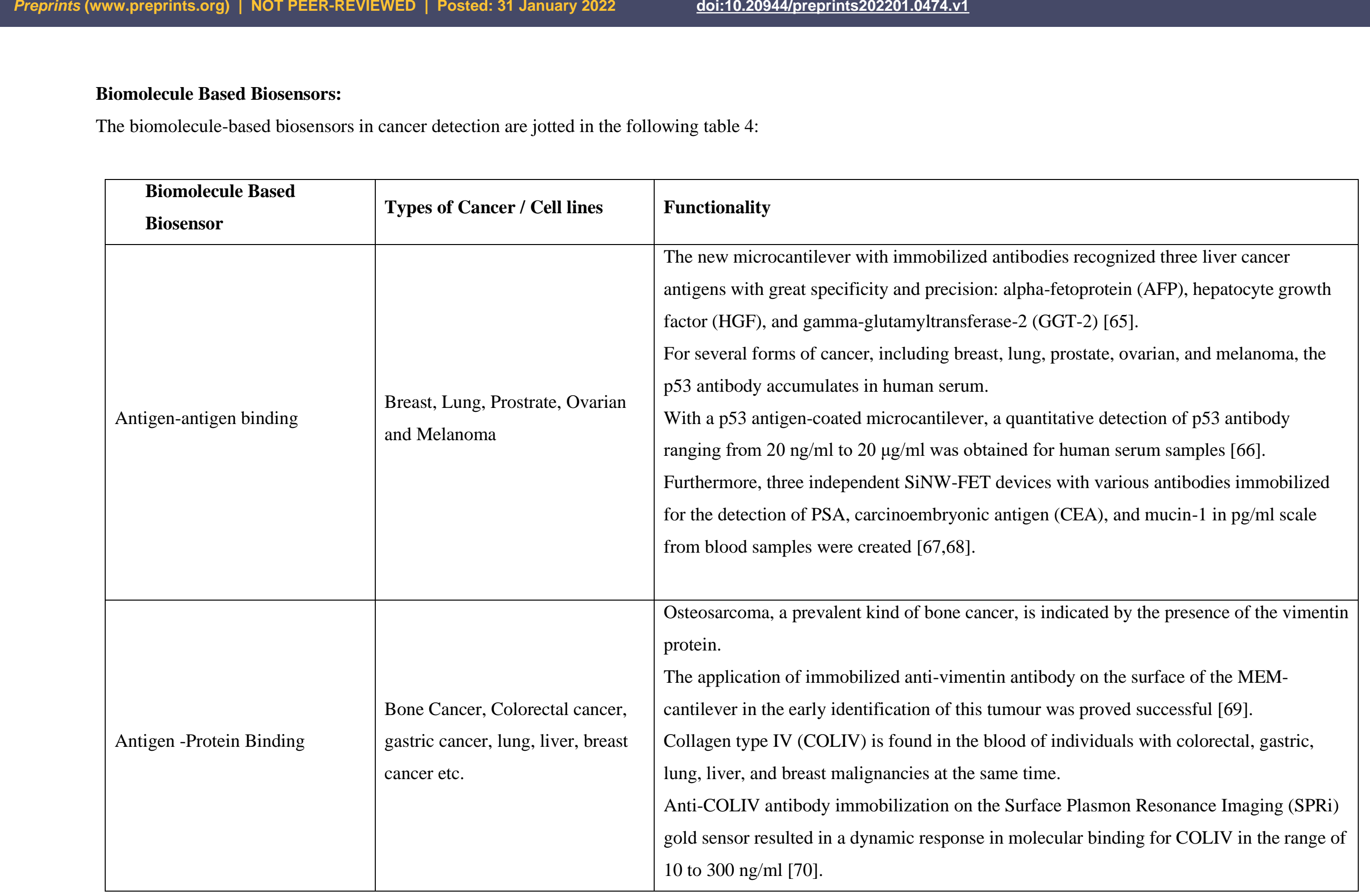




\begin{tabular}{|c|c|c|}
\hline & & $\begin{array}{l}\text { Depending on the state of proteolytic processing, the laminin- } 5 \text { protein acts as a motility or } \\
\text { adhesive factor. } \\
\text { It may increase tumor invasion by interacting with various cell-surface receptors. } \\
\text { The content of laminin- } 5 \text { in blood plasma was determined using an antibody-based SPRi } \\
\text { biosensor with a detection limit of } 4 \mathrm{pg} / \mathrm{ml}[71] \text {. }\end{array}$ \\
\hline Protein -DNA binding & Breast Cancer & $\begin{array}{l}\text { The UV-irradiated DNA sequence derived from human cell extracts may also be semi- } \\
\text { quantitatively detected using the SPR technique. The biotinylated DNA sequence was } \\
\text { recorded on a streptavidin-coated sensor chip [72]. The DNA functionalized (SiNW-FET) } \\
\text { biosensor can also be used to analyze protein-DNA binding. The estrogen receptor alpha } \\
\text { (ER } \alpha, \text { protein) controls gene expression by binding directly to estrogen receptor sequences } \\
\text { (ERE } \alpha, \text { dsDNA) immobilized on the sensor, which can be utilized to detect protein-DNA } \\
\text { interactions in nuclear extracts from breast cancer cells. The developed biosensor was } \\
\text { capable of detecting ER } \alpha \text { at a concentration of } 10 \mathrm{fM} \mathrm{[73].}\end{array}$ \\
\hline
\end{tabular}




\begin{tabular}{|l|l|l|}
\hline Lectin-carbohydrate binding & Leukemia cell line & $\begin{array}{l}\text { The binding kinetics of lectin-carbohydrate interactions is gaining attention due to the fact } \\
\text { that cancer cells change their glycosylation profile as they advance, which could be a } \\
\text { potential therapeutic target [74]. } \\
\text { Two mannose-specific lectins (Lens culinaris and Concanavalin A, Con A) were } \\
\text { immobilized on gold QCM-D sensors using thiol groups, and carboxypeptidase Y was } \\
\text { added to the buffer solution after that. In cancer research, lectin to carbohydrate affinity } \\
\text { analysis could be used as a fast biomarker categorization assay [75]. } \\
\text { Moreover, an intriguing use of lectin-based sensors for cells in suspension was } \\
\text { accomplished. The addition of Con A to the QCM sensor caused the human leukemia cell } \\
\text { line to bind, which was followed by the attachment of the second lectin on top of the cells. } \\
\text { This strategy could lead to the creation of a new label-free suspension cell-based biosensor } \\
\text { [76]. }\end{array}$ \\
\hline
\end{tabular}


SPR based Biosensors : Surface plasmon resonance (SPR)-based biosensing technologies are utilized to construct a variety of biosensors for the diagnosis of mutagenic cells as a label-free detection approaches [77]. Research by fellow scientist have developed an SPR biosensing device for cancer biomarker detection in human serum samples [78].

In the experiment, total prostate-specific antigen (tPSA) was employed. When $20 \mathrm{~nm}$ gold nanoparticles (antibody functionalized) were utilized, the detection limit for tPSA detection in 75 percent human serum was $2.3 \mathrm{ng} \mathrm{mL}-1$, but with $40 \mathrm{~nm}$ gold nanoparticles it was $0.29 \mathrm{ng} \mathrm{mL}-1$. The SPR biosensor's diagnosis outcome were compared to those of a QCM, suggesting that the created SPR biosensor chip may be utilized to search for cancer biomarkers (figure 3). Cennamo et al. [79] devised a simple method for designing an SPR aptasensor based on plastic optical fiber for cancer biomarker diagnosis. The found tumourgenic biomarker in this investigation is vascular endothelial growth factor (VEGF), as the levels of are related to cancer patients in medical diagnosis. Two factors are primarily responsible for the identification of cancer biomarkers. On the one hand, the chosen aptamers of DNA have very high affinity and specificity for the target of study, allowing the high efficiency of detection signal to be collected. On the other hand, the SPR biosensor's distinctive light directing structure is particularly well suited to biosensor implementation and can expose interface features. Consequently, an SPR biosensor could be used to diagnosis cancer cells on the go.

Figure 3: SPR based biosensor technology

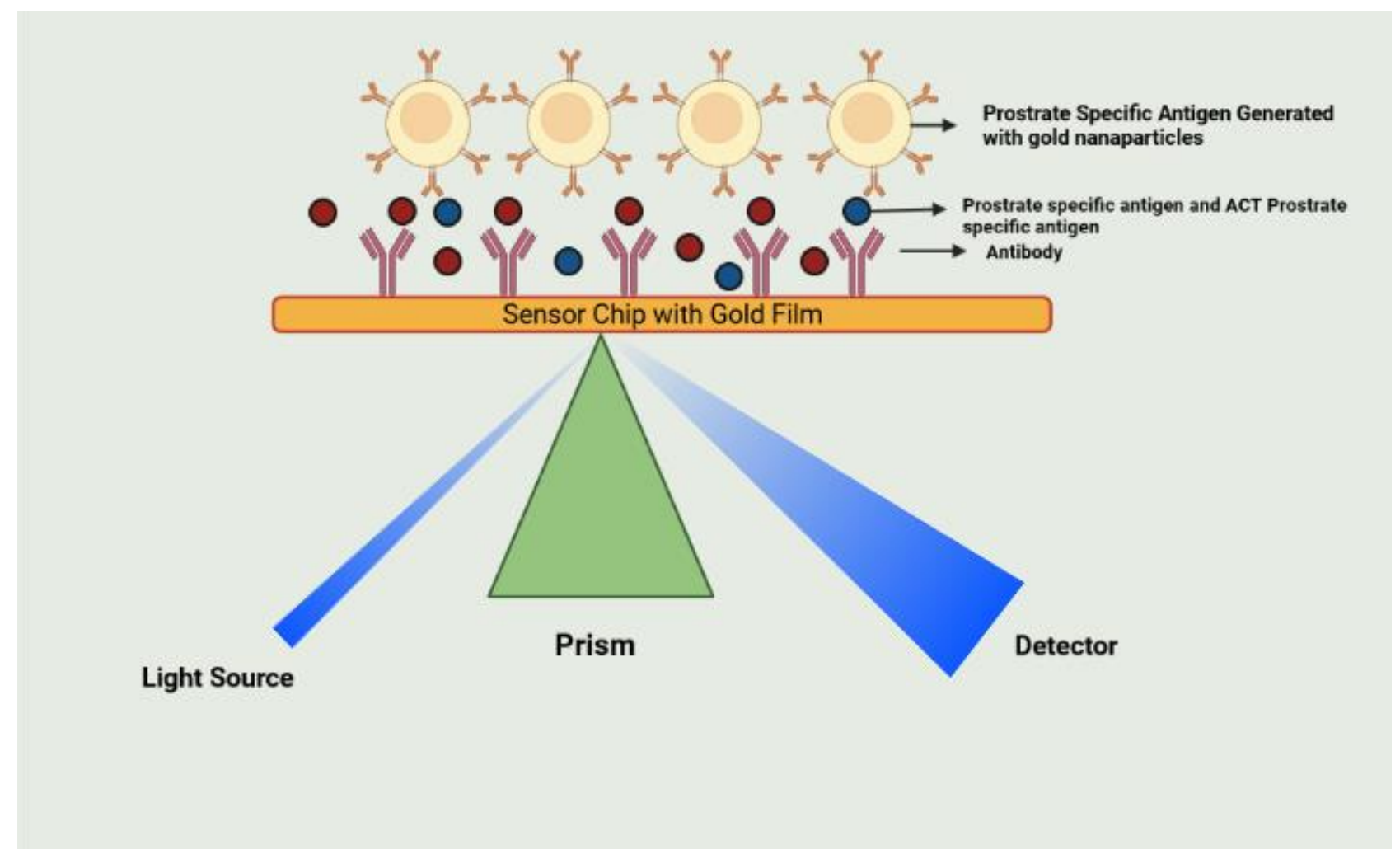


SPR-based biosensors can also detect cancer biomarkers such as breast cancer gene-1 and 2 early onset (BRCA1 and BRCA2). For the diagnosis of breast cancer biomarkers BRCA1 and BRCA2, A study have. employed a numerical simulation of the graphene-coated fiber SPR biosensor. The attenuated total reflection (ATR) approach was employed in these biosensors to detect breast cancer biomarkers, and to probe deoxyribonucleic acid (DNA) hybridization the variations in SPR angle and surface resonance frequency (SRF) were used . Breast carcinogenic and non-cancerous cells were differentiated using an SPR biosensor, resulting in a new breast cancer detection tool.

Surface-enhanced Raman scattering biosensors: SERS (surface-enhanced Raman scattering) is a strong diagnosis method used in biomedical science, clinical diagnosis, and the environment. Tumorgenic biomarkers, pathogen microorganisms, and viruses have all been successfully detected using SERS-based biosensing approaches in recent years [81]. Despite the widespread usage of SERS-based biosensing techniques in a variety of sectors, the creation of genuine SERS-based sensors for experimental applications is very rare to be documented. Research led by group of scientists have. constructed a portable SERS spectrometer to detect breast cancer biomarkers from tears of humans by using the ultra-sensitivity of the SERS sensing approach [82]. Figure 2 shows the Au-deposited SERS substrate. They were able to control the standard deviation of reproducibility and reliability to within five percent using a multivariate statisticsbased identification technique. Wang et al. [83] employed porous CuFeSe2/Au heterostructured nanospheres to make a surface enhanced Ramen scattering biosensors for diagnosing lung cancer and cancer biomarkers. The Raman-active sensing molecule paminothiophenol (4-ATP) was applied onto the surface of $\mathrm{CuFeSe} 2 / \mathrm{Au}$ heterostructured nanospheres in this study. As a result of the $\mathrm{C}=\mathrm{N}$ connection, aldehyde molecules which are gaseous can easily adsorb onto nanoparticle surfaces, with a detection limit of $1.0 \mathrm{ppb}$. In addition, $\mathrm{CuFeSe} 2 / \mathrm{Au}$ heterostructured nanospheres modified with folic acid (FA) can be employed to recognize and detect A549 cells [84].

\section{Conclusion :}

Since cancer can rapidly spread, possible new approaches must be simple to gauge, quick to test, and inexpensive. As a result, biosensor approaches, particularly those that use label-free detection, have recently received a lot of interest. Their key assumption is that the biorecognition element and the selected analyte have a specific relationship.

There is a great demand for effective biosensors for rapid analysis of cellular modifications to detect relevant biomarkers in order to improve cancer prognosis and treatment techniques. Biosensor devices, on the other hand, must be progressively developed to meet new problems, such as multiplex analysis of numerous biomarkers, which necessitates the development of arrays of sensors on the same chip. Future advancements in biosensor technology, like as biomarkers, patterning software, and microfluidics, could make these devices extremely useful in this field. The use of nanomaterials in the creation of biomarker detection sensors will make these devices more sensitive and useful for point-of-care early diagnosis. Early detection 
will help to improve survival rates, and the successful development of biosensors for cancer diagnostics will necessitate adequate financing to take the technology from research to commercialization.

\section{Declarations}

1. Conflict of Interest: None

2. Informed Consent: N/A

3. Compliance with ethical standards: N/A

4. Acknowledgements: None. 


\section{Reference:}

1. Jemal, A.; Siegel, R.; Ward, E.; Murray, T.; Xu, J.; Smigal, C.; Thun, M. J. Cancer Statistics, 2006. CA Cancer J. Clin. 2006, 56 (2), 106-130. https://doi.org/10.3322/canjclin.56.2.106.

2. Gunawardana, C. G.; Diamandis, E. P. High Throughput Proteomic Strategies for Identifying Tumour-Associated Antigens. Cancer Lett. 2007, 249 (1), 110-119. https://doi.org/10.1016/j.canlet.2007.01.002.

3. Cancer mortality statistics https://www.cancerresearchuk.org/health-professional/cancerstatistics/mortality (accessed $2022-01-24)$.

4. Altintas, Z.; Tothill, I. Biomarkers and Biosensors for the Early Diagnosis of Lung Cancer. Sens. Actuators B Chem. 2013, 188, 988-998. https://doi.org/10.1016/j.snb.2013.07.078.

5. del Sol, A.; Balling, R.; Hood, L.; Galas, D. Diseases as Network Perturbations. Curr. Opin. Biotechnol. 2010, 21 (4), 566-571. https://doi.org/10.1016/j.copbio.2010.07.010.

6. Jayanthi, V. S. P. K. S. A.; Das, A. B.; Saxena, U. Recent Advances in Biosensor Development for the Detection of Cancer Biomarkers. Biosens. Bioelectron. 2017, 91, 15-23. https://doi.org/10.1016/j.bios.2016.12.014.

7. Ranjan, R.; Esimbekova, E. N.; Kratasyuk, V. A. Rapid Biosensing Tools for Cancer Biomarkers. Biosens. Bioelectron. 2017, 87, 918-930. https://doi.org/10.1016/j.bios.2016.09.061.

8. Grieshaber, D.; Mackenzie, R.; Voros, J.; Reimhult, E. Electrochemical Biosensors- Sensor Principles and Architectures. Sensors 2008, 8 (3), 1400-1458. https://doi.org/10.3390/s8031400.

9. Sankara, V.; Jayanthi, A.; Das, A. B. Recent Advances in Biosensor Development for the Detection of Cancer Biomarkers. Biosensors and Bioelectronics 2007, 91 (15), 15-23.

10. Fong, Z. V.; Winter, J. M. Biomarkers in Pancreatic Cancer: Diagnostic, Prognostic, and Predictive. The Cancer. J 2012, 18 (6), 530-538.

11. Hayes, D. F.; Bast, R. C.; Desch, C. E.; Fritsche, H., Jr; Kemeny, N. E.; Jessup, J. M.; Locker, G. Y.; Macdonald, J. S.; Mennel, R. G.; Norton, L.; Ravdin, P.; Taube, S.; Winn, R. J. Tumor Marker Utility Grading System: A Framework to Evaluate Clinical Utility of Tumor Markers. J. Natl. Cancer Inst. 1996, 88 (20), 1456-1466. https://doi.org/10.1093/jnci/88.20.1456

12. Chatterjee, S. K.; Zetter, B. R. Cancer Biomarkers: Knowing the Present and Predicting the Future. Future Oncol. 2005, 1 (1), 37-50. https://doi.org/10.1517/14796694.1.1.37.

13. Kumar, S.; Mohan, A.; Guleria, R. Biomarkers in Cancer Screening, Research and Detection: Present and Future: A Review. Biomarkers 2006, 11 (5), 385-405. https://doi.org/10.1080/13547500600775011

14. Ahn, C. H.; Choi, J. W.; Beaucage, G.; Nevin, J. H.; Lee, J. B.; Puntambekar, A. Dis- Posable Smart Lab on a Chip for Point-of-Care Clinical Diagnostics. Proc IEEE 2004, 92, 154-173.

15. Souza, D. Microbial Biosensors. Biosensors \& Bioelectronics 2001, 16, 337-353.

16. Biosensors: Fundamentals and Applications, Mir Publishers, Moscow. In Biosensors: Fundamentals and Applications; Wilson, M. G., Ed.; Mir Publishers, 1992.

17. Souza, D. Immobilized Enzymes in Bioprocess. Curr. Sci 1999, 77, 69-79 
18. Malhotra, B. D.; Singhal, R.; Chaubey, A.; Sharma, S. K.; Kumar, A. Recent Trends in Biosensors. Curr. Appl. Phys. 2005, 5 (2), 92-97. https://doi.org/10.1016/j.cap.2004.06.021

19. Bilitewski, U.; Turner, A. Biosensors for Environmental Monitoring; Harwood Academic: Amsterdam, 2000.

20. Koyambo-Konzapa, S-J.; Mbesse Kongbonga G.Y.; Premkumar, R.; Duvalier Ramlina Vamhindi, B.S.; Nsangou, M.; Milton Franklin Benial, A. Spectroscopic, quantum chemical, molecular docking and molecular dynamics investigations of hydroxylic indole-3-pyruvic acid: a potent candidate for nonlinear optical applications and Alzheimer's drug. J. Biomol. Struct. Dyn. 2021, 10.1080/07391102.2021.1947380.

21. Matrubutham, U.; Sayler, G. S. Microbial Biosensors Based on Optical Detection. In Enzyme and Microbial Biosensors; Humana Press: New Jersey, 2003; pp 249-256.

22. Lazcka, O.; Del Campo, F. J.; Muñoz, F. X. Pathogen Detection: A Perspective of Traditional Methods and Biosensors. Biosens. Bioelectron. 2007, 22 (7), 1205-1217.

https://doi.org/10.1016/j.bios.2006.06.036.

23. Quazi, S., 2021. Elucidation of CRISPR-Cas9 Application in Novel Cellular Immunotherapy. Preprints.org,

24. Watts, H. J.; Lowe, C. R.; Pollard-Knight, D. V. Optical Biosensor for Monitoring Microbial Cells. Anal. Chem. 1994, 66 (15), 2465-2470. https://doi.org/10.1021/ac00087a010

25. Syam, R.; Davis, K.; Pratheesh, M. D.; Anoopraj, R.; Joseph, S. Biosensors: A Novel Approach for Pathogen Detection. Biosensors: A Novel Approach for Pathogen Detection. VETSCAN 2012, 7, $14-$ 18.

26. Homola, J.; Yee, S. S.; Gauglitz, G. Surface Plasmon Resonance Sensors: Review. Sens. Actuators B Chem. 1999, 54 (1-2), 3-15. https://doi.org/10.1016/s0925-4005(98)00321-9.

27. Higson, S. P. J.; Reddy, S. M.; Vadgama, P. M. Enzyme and Other Biosensors: Evolution of a Technology. Eng. Sci. Educ. J. 1994, 3 (1), 41-48. https://doi.org/10.1049/esej:19940105.

28. Wang, J.; Rivas, G.; Cai, X.; Palecek, E.; Nielsen, P.; Shiraishi, H.; Dontha, N.; Luo, D.; Parrado, C.; Chicharro, M.; Farias, P.; Valera, F. S. DNA Electrochemical Biosensors for Environmental Monitoring: A Review. Anal Chim Acta 1997, 347, 1-8.

29. Rai, M.; Gade, A.; Gaikwad, S.; Marcato, P. D.; Durán, N. Biomedical Applications of Nanobiosensors: The State-of-the-Art. J. Braz. Chem. Soc. 2012. https://doi.org/10.1590/s0103$\underline{50532012000100004 .}$

30. Abu-Salah, K. M.; Zourob, M. M.; Mouffouk, F.; Alrokayan, S. A.; Alaamery, M. A.; Ansari, A. A. DNABased Nanobiosensors as an Emerging Platform for Detection of Disease. Sensors (Basel) 2015, 15 (6), 14539-14568. https://doi.org/10.3390/s150614539.

31. Bohunicky, B.; Mousa, S. A. Biosensors: The New Wave in Cancer Diagnosis. Nanotechnol. Sci. Appl. 2010, 4, 1-10. https://doi.org/10.2147/NSA.S13465. 
32. Wikipedia contributors. Leland Clark https://en.wikipedia.org/w/index.php?title=Leland Clark\&oldid=1054345281.

33. Chang, J.; Wang, X.; Wang, J.; Li, H.; Li, F. Nucleic Acid-Functionalized Metal Organic FrameworkBased Homogeneous Electrochemical Biosensor for Simultaneous; 2019.

34. Zhang, X.; Yu, Y.; Shen, J.; Qi, W.; Wang, H. Design of Organic/Inorganic Nanocomposites for Ultrasensitive Electrochemical Detection of a Cancer Biomarker Protein. Talanta 2020, 212 (120794), 120794. https://doi.org/10.1016/j.talanta.2020.120794.

35. Khanmohammadi, A.; Aghaie, A.; Vahedi, E.; Qazvini, A.; Ghanei, M.; Afkhami, A.; Hajian, A.; Bagheri, H. Electrochemical Biosensors for the Detection of Lung Cancer Biomarkers: A Review. Talanta 2020, 206 (120251), 120251. https://doi.org/10.1016/j.talanta.2019.120251.

36. Gavas, S., Quazi, S. and Karpiński, T., 2021. Nanoparticles for Cancer Therapy: Current Progress and Challenges. Nanoscale Research Letters, 16(1).

37. Bora, U. Nucleic Acid Based Biosensors for Clinical Applications. Biosens. J. 2013, 02 (01). https://doi.org/10.4172/2090-4967.1000104.

38. Kilic, T.; Topkaya, S. N.; Ozkan Ariksoysal, D.; Ozsoz, M.; Ballar, P.; Erac, Y.; Gozen, O. Electrochemical Based Detection of MicroRNA, Mir21 in Breast Cancer Cells. Biosens. Bioelectron. 2012, 38 (1), 195-201. https://doi.org/10.1016/i.bios.2012.05.031.

39. Zhang, G.-J.; Chua, J. H.; Chee, R.-E.; Agarwal, A.; Wong, S. M. Label-Free Direct Detection of MiRNAs with Silicon Nanowire Biosensors. Biosens. Bioelectron. 2009, 24 (8), 2504-2508. https://doi.org/10.1016/i.bios.2008.12.035.

40. Sohrabi, N.; Valizadeh, A.; Farkhani, S. M.; Akbarzadeh, A. Basics of DNA Biosensors and Cancer Diagnosis. Artif. Cells Nanomed. Biotechnol. 2016, 44 (2), 654-663. https://doi.org/10.3109/21691401.2014.976707.

41. Mansor, N. A.; Zain, Z. M.; Hamzah, H. H.; Noorden, M. S. A.; Jaapar, S. S.; Beni, V.; Ibupoto, Z. H. Detection of Breast Cancer 1 (BRCA1) Gene Using an Electrochemical DNA Biosensor Based on Immobilized ZnO Nanowires. Open j. appl. biosens. 2014, 03 (02), 9-17. https://doi.org/10.4236/ojab.2014.32002

42. Shan, W.; Pan, Y.; Fang, H.; Guo, M.; Nie, Z.; Huang, Y.; Yao, S. An Aptamer-Based Quartz Crystal Microbalance Biosensor for Sensitive and Selective Detection of Leukemia Cells Using SilverEnhanced Gold Nanoparticle Label. Talanta 2014, 126, 130-135. https://doi.org/10.1016/j.talanta.2014.03.056.

43. Formisano, N.; Jolly, P.; Bhalla, N.; Cromhout, M.; Flanagan, S. P.; Fogel, R.; Limson, J. L.; Estrela, P. Optimisation of an Electrochemical Impedance Spectroscopy Aptasensor by Exploiting Quartz Crystal Microbalance with Dissipation Signals. Sens. Actuators B Chem. 2015, 220, 369-375. https://doi.org/10.1016/i.snb.2015.05.049. 
44. Calabretta, M. M.; Montali, L.; Lopreside, A.; Fragapane, F.; lacoangeli, F.; Roda, A.; Bocci, V.; D’Elia, M.; Michelini, E. Ultrasensitive On-Field Luminescence Detection Using a Low-Cost Silicon Photomultiplier Device. Anal. Chem. 2021, 93 (20), 7388-7393.

https://doi.org/10.1021/acs.analchem.1c00899.

45. Dey, D.; Goswami, T. Optical Biosensors: A Revolution towards Quantum Nanoscale Electronics Device Fabrication. J. Biomed. Biotechnol. 2011, 2011, 348218. https://doi.org/10.1155/2011/348218.

46. Valarmathi, T.; Premkumar, R.; Milton Franklin Benial, A. Spectroscopic and molecular docking studies on 1-Hydroxyanthraquinone: A potent ovarian cancer drug. J. Mol. Struct. 2020, 1213, 128163.

47. Tothill, I. E. Biosensors for Cancer Markers Diagnosis. Semin. Cell Dev. Biol. 2009, 20 (1), 55-62. https://doi.org/10.1016/j.semcdb.2009.01.015.

48. Quazi, S., 2021. Vaccine in response to COVID-19: Recent developments, challenges, and a way out. Biomedical and Biotechnology Research Journal (BBRJ), 5(2), p.105.

49. Chan, L. L.; Gosangari, S. L.; Watkin, K. L.; Cunningham, B. T. A Label-Free Photonic Crystal Biosensor Imaging Method for Detection of Cancer Cell Cytotoxicity and Proliferation. Apoptosis 2007, 12 (6), 1061-1068. https://doi.org/10.1007/s10495-006-0031-y.

50. Jacobson, K. Biosensors and Other Medical and Environmental Probes; United States.

51. Dell'Atti, D.; Tombelli, S.; Minunni, M.; Mascini, M. Detection of Clinically Relevant Point Mutations by a Novel Piezoelectric Biosensor. Biosens. Bioelectron. 2006, 21 (10), 1876-1879. https://doi.org/10.1016/j.bios.2005.11.023

52. Chaplin M.What are biosensors? 2004Available from: http://www.lsbu.ac.uk/biology/enztech/biosensors.htmlAccessed Sep 242010

53. Medley, C. D.; Smith, J. E.; Tang, Z.; Wu, Y.; Bamrungsap, S.; Tan, W. Gold Nanoparticle-Based Colorimetric Assay for the Direct Detection of Cancerous Cells. Anal. Chem. 2008, 80 (4), 10671072. https://doi.org/10.1021/ac702037y.

54. Peiris, D.; Markiv, A.; Curley, G. P.; Dwek, M. V. A Novel Approach to Determining the Affinity of Protein- Carbohydrate Interactions Employing Adherent Cancer Cells Grown on a Biosensor Surface. Biosensors and Bioelectronics 2012, 35, 160-166.

55. Valarmathi, T.; Premkumar, R.; Meera, M.R; Milton Franklin Benial, A. Spectroscopic, Quantum Chemical and Molecular Docking Studies on 1-Amino-5chloroanthraquinone: A Targeted Drug Therapy for Thyroid Cancer. Spectrochim. Acta 2021, 255(3), 119659.

56. Peiris, D.; Spector, A. F.; Lomax-Browne, H.; Azimi, T.; Ramesh, B.; Loizidou, M.; Welch, H.; Dwek, M. V. Cellular Glycosylation Affects Herceptin Binding and Sensitivity of Breast Cancer Cells to Doxorubicin and Growth Factors. Sci. Rep. 2017, 7, 43006. https://doi.org/10.1038/srep43006. 
57. Lu, J.; Yang, Y.; Wang, W.; Li, J.; Tao, N.; Wang, S. Label-Free Imaging of Histamine Mediated G Protein Coupled Receptors Activation in Live Cells. Analytical Chemistry 2016, 88 (23), 1149811503.

58. Clausen, T. M.; Pereira, M. A.; Oo, H. Z.; Resende, M.; Gustavson, T.; Mao, Y.; Sugiura, N.; Liew, J.; Fazli, L.; Theander, T. G.; Daugaard, M.; Salanti, A. Real-Time and Label Free Determination of Ligand Binding-Kinetics to Primary Cancer Tissue Specimens; a Novel Tool for the Assessment of Biomarker Targeting. Sens. BioSensing Res. 2016, 9, 23-30.

https://doi.org/10.1016/j.sbsr.2016.05.003.

59. Quazi, S., 2021. An overview of CAR T cell mediated B cell Maturation Antigen therapy. Clinical Lymphoma Myeloma and Leukemia.

60. Suutari, T.; Silen, T.; S en Karaman, D.; Saari, H.; Desai, D.; Kerkelä, E.; Laitinen, S.; Hanzlikova, M.; Rosenholm, J. M.; Yliperttula, M.; Viitala, T. Real-Time Label-Free Monitoring of Nanoparticle Cell Uptake. Small 2016, 12 (45), 6289-6300. https://doi.org/10.1002/smll.201601815.

61. Iturri, J.; García-Fernández, L.; Reuning, U.; García, A. J.; del Campo, A.; Salierno, M. J. Synchronized Cell Attachment Triggered by Photo-Activatable Adhesive Ligands Allows QCM-Based Detection of Early Integrin Binding. Sci. Rep. 2015, 5 (1), 9533. https://doi.org/10.1038/srep09533.

62. Quazi, S., 2021. Artificial Intelligence and Machine Learning in Precision and Genomic Medicine. Preprints.org,

63. Orgovan, N.; Peter, B.; Bősze, S.; Ramsden, J. J.; Szabó, B.; Horvath, R. Dependence of Cancer Cell Adhesion Kinetics on Integrin Ligand Surface Density Measured by a High-Throughput Label-Free Resonant Waveguide Grating Biosensor. Sci. Rep. 2014, 4 (1), 4034.

https://doi.org/10.1038/srep04034.

64. Ishay, R. B.; Kapp-Barnea, Y.; Grigoriantz, I.; Teblum, E.; Lellouche, J.-P. Real Time Acoustic Profiling of a Live Cancerous Cell Monolayer Using QCM. Sens. Actuators B Chem. 2015, 215, 373-381. https://doi.org/10.1016/i.snb.2015.03.091.

65. Quazi, S., 2021. Telomerase Gene Therapy: A Remission Towards Cancer. Preprints.org,

66. Wang, J.; Zhu, Y.; Wang, X.; Wang, S.; Yang, J.; Yang, F. A High-Throughput Cantilever Array Sensor for Multiple Liver Cancer Biomarkers Detection. IEEE Sens. J. 2016, 16 (12), 4675-4682. https://doi.org/10.1109/jsen.2016.2524515.

67. Zhou, Y.; Wang, Z.; Yue, W.; Tang, K.; Ruan, W.; Zhang, Q.; Liu, L. Label-Free Detection of P53 Antibody Using a Microcantilever Biosensor with Piezoresistive Readout. In 2009 IEEE Sensors; IEEE, 2009.

68. Chen, K.-I.; Li, B.-R.; Chen, Y.-T. Silicon Nanowire Field-Effect Transistor-Based Biosensors for Biomedical Diagnosis and Cellular Recording Investigation. Nano Today 2011, 6 (2), 131-154. https://doi.org/10.1016/i.nantod.2011.02.001 
69. Balwir, S. P.; Sahare, M.; Raghuwanshi, A.; Angarwar, S.; Fulzele, R. Design of Cantilever Based Biosensor for Bone Cancer Detection. International Journal of Research in Engineering and Technology 2016, No. 5.

70. Sankiewicz, A.; Lukaszewski, Z.; Trojanowska, K.; Gorodkiewicz, E. Determination of Collagen Type IV by Surface Plasmon Resonance Imaging Using a Specific Biosensor. Anal. Biochem. 2016, 515, 40-46. https://doi.org/10.1016/j.ab.2016.10.002.

71. Sankiewicz, A.; Romanowicz, L.; Laudanski, P.; Zelazowska-Rutkowska, B.; Puzan, B.; Cylwik, B.; Gorodkiewicz, E. SPR Imaging Biosensor for Determination of Laminin-5 as a Potential Cancer Marker in Biological Material. Anal. Bioanal. Chem. 2016, 408 (19), 5269-5276. https://doi.org/10.1007/s00216-016-9621-x

72. Ahmed, F. E.; Wiley, J. E.; Weidner, D. A.; Bonnerup, C.; Mota, H. Surface Plasmon Resonance (SPR) Spectrometry as a Tool to Analyze Nucleic Acid-Protein Interactions in Crude Cellular Extracts. Cancer Genomics Proteomics 2010, 7 (6), 303-309.

73. Zhang, G.-J.; Huang, M. J.; Ang, J. J.; Liu, E. T.; Desai, K. V. Self-Assembled Monolayer-Assisted Silicon Nanowire Biosensor for Detection of Protein-DNA Interactions in Nuclear Extracts from Breast Cancer Cell. Biosens. Bioelectron. 2011, 26 (7), 3233-3239.

https://doi.org/10.1016/i.bios.2010.12.032.

74. Senkara-Barwijuk, E.; Kobiela, T.; Lebed, K.; Lekka, M. Reaction Pathway and Free Energy Profile Determined for Specific Recognition of Oligosaccharide Moiety of Carboxypeptidase Y. Biosens. Bioelectron. 2012, 36 (1), 103-109. https://doi.org/10.1016/i.bios.2012.04.014.

75. Quazi, S., 2021. TNFR2 Antagonist and Agonist: A Potential Therapeutics in Cancer Immunotherapy. Preprints.org.

76. Li, X.; Pei, Y.; Zhang, R.; Shuai, Q.; Wang, F.; Aastrup, T.; Pei, Z. A Suspension-Cell Biosensor for RealTime Determination of Binding Kinetics of Protein-Carbohydrate Interactions on Cancer Cell Surfaces. Chem. Commun. (Camb.) 2013, 49 (85), 9908-9910. https://doi.org/10.1039/c3cc45006f.

77. C. Liu et al., Sensitive detection of exosomal proteins via a compact surface plasmon resonance 78. biosensor for cancer diagnosis. ACS sensors 3, 1471-1479 (2018).

79. Uludag, Y.; Tothill, I. E. Cancer Biomarker Detection in Serum Samples Using Surface Plasmon Resonance and Quartz Crystal Microbalance Sensors with Nanoparticle Signal Amplification. Anal. Chem. 2012, 84 (14), 5898-5904. https://doi.org/10.1021/ac300278p.

80. Cennamo, N.; Pesavento, M.; Lunelli, L.; Vanzetti, L.; Pederzolli, C.; Zeni, L.; Pasquardini, L. An Easy Way to Realize SPR Aptasensor: A Multimode Plastic Optical Fiber Platform for Cancer Biomarkers Detection. Talanta 2015, 140, 88-95. https://doi.org/10.1016/j.talanta.2015.03.025.

81. Hossain, M. B.; Islam, M. M.; Abdulrazak, L. F.; Rana, M. M.; Akib, T. B. A.; Hassan, M. GrapheneCoated Optical Fiber SPR Biosensor for BRCA1 and BRCA2 Breast Cancer Biomarker Detection: A 
Numerical Design-Based Analysis. Photonic Sens. 2020, 10 (1), 67-79.

https://doi.org/10.1007/s13320-019-0556-7.

82. Yeganeh, F., Yeganeh, A., Far, B., Akbarzadeh, I., Quazi, S. and Safdar, M., 2021. In-Vitro Cytotoxicity and Anticancer Drug Release Behavior of Methionine - Coated Magnetite Nanoparticles as Carriers.

83. Pilot, R.; Signorini, R.; Durante, C.; Orian, L.; Bhamidipati, M.; Fabris, L. A Review on SurfaceEnhanced Raman Scattering. Biosensors (Basel) 2019, 9 (2), 57. https://doi.org/10.3390/bios9020057.

84. Kim, S.; Kim, T. G.; Lee, S. H.; Kim, W.; Bang, A.; Moon, S. W.; Song, J.; Shin, J.-H.; Yu, J. S.; Choi, S. Label-Free Surface-Enhanced Raman Spectroscopy Biosensor for on-Site Breast Cancer Detection Using Human Tears. ACS Appl. Mater. Interfaces 2020, 12 (7), 7897-7904. https://doi.org/10.1021

85. Wen, H.; Wang, H.; Hai, J.; He, S.; Chen, F.; Wang, B. Photochemical Synthesis of Porous CuFeSe2/Au Heterostructured Nanospheres as SERS Sensor for Ultrasensitive Detection of Lung Cancer Cells and Their Biomarkers. ACS Sustain. Chem. Eng. 2019, 7 (5), 5200-5208. https://doi.org/10.1021/acssuschemeng.8b06116. 